\title{
Original Research \\ Assessment of Biodiversity in the Context of the 'Greening' Requirements of Farms Located in Natura 2000 Dąbrowy Krotoszyńskie (PLH300002) and Its Adjacent Zone
}

\author{
Jerzy M. Kupiec* \\ Department of Ecology and Environmental Protection, Poznań University of Life Sciences, \\ Piątkowska 94 C, 60-649 Poznań, Poland \\ Received: 5 November 2014 \\ Accepted: 11 December 2014
}

\begin{abstract}
The aim of this paper is to evaluate the species diversity of crops and livestock in chosen farms located in a Natura 2000 area, in terms of the variety of agricultural production and land. Seventy-five farms with an average size of 37.8 ha were chosen to be included in the study, all of which are involved in the production of crops and livestock. The diversity of the agricultural land in the group of 75 farms was low and was mainly dominated by arable land. The range of crops cultivated by farmers was quite narrow and did not exceed 13 species. On average, there were seven crop species on each farm plus a total of nine species of animals, on average two species per farm, of which the most common were cattle and pigs. Animals other than cattle and pigs accounted for only $1.3 \%$ of the total.
\end{abstract}

Keywords: Dąbrowy Krotoszyńskie, biodiversity, agricultural indicators, 'greening' requirements

\section{Introduction}

Biodiversity in agriculture can be considered on two levels. The first is the biological diversity of wild plants and animals in rural agricultural production areas, as well as in natural habitats. The second level concerns the diversity of species and varieties of plants cultivated by man and also the species and breeds of domesticated animals. Protection of agro-diversity has become a priority in many countries around the world. Humans have cultivated approximately 7,000 species of plants over the last 12,000 years, although currently there are far fewer. Only 15 species of plants and nine species of animals provide about $90 \%$ of the total food production in the world [1]. Nearly half of the world's food derived from plants is provided by only four species: rice,

*e-mail: jkupiec@up.poznan.pl corn, wheat, and potatoes. FAO data indicate that half of the breeds occurring in Europe at the beginning of the $20^{\text {th }}$ century have died out, and now approx. 30\% are endangered. According to The State of the World's Animal Genetic Resources for Food and Agriculture [2], 1,491 of 7,616 species of domestic animals may be completely extinct in the near future. Conventional industrialized agriculture affects the impoverishment of biodiversity agrocenosis [3].

In 1992, to protect the biodiversity of natural and agricultural ecosystems, the Convention on Biological Diversity (CBD) was drawn up [4]. The importance of biodiversity, the scale of its impact on the environment, and its social ramifications are evidenced by the fact that in 2010 the List of Parties (list of parties to the convention) numbered over 193 participants. On the basis of the convention, ratified by Poland in 1996, the Ministry of Environment developed the National Strategy for the Conservation and 
Sustainable Use of Biodiversity [5]. According to the strategy it is necessary to protect the planet's ecosystems at all levels, including those elements that have so far been neglected or even destroyed, such as pests or weeds. The provisions of the convention also pay attention to the value of areas used commercially, including the diversity of old, traditional varieties of crops and breeds and species of livestock, and the need to treat them so as to ensure their stability and reproducibility.

On par with natural ecosystems and agrocenosis should also be the protection of traditional folk knowledge and

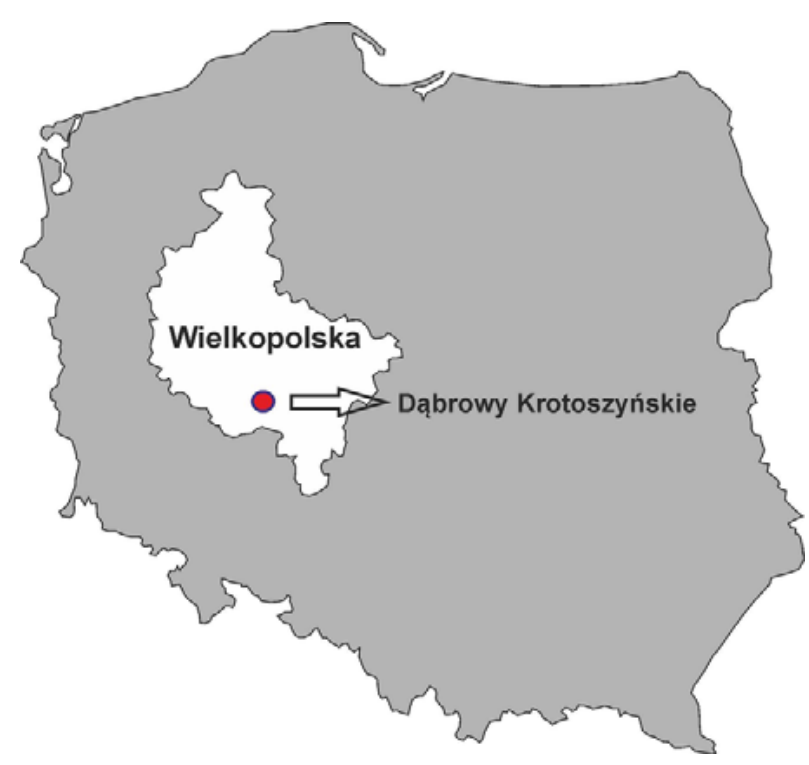

Fig. 1. Location of the NATURA 2000 Dąbrowy Krotoszyńskie area in Poland. practices conducive to the conservation and sustainable use of biological diversity $[6,7]$. Even the Copa-Cogeca joined in order to protect biodiversity and represent European farmers in terms of diversification of agricultural production.

The aim of this study is to evaluate the species diversity of crops and livestock in selected farms in a Natura 2000 area, in terms of variety of agricultural production and land.

\section{Material and Methods}

The 75 chosen farms are located in Dabrowy Krotoszyńskie, within a zone with a direct effect on this Natura 2000 area. Dąbrowy Krotoszyńskie is in southern Wielkopolska Province (Figs. 1, 2). The degree to which the selected farms have implemented the requirements of 'greening' was rated. Data from 2004-11 were used in the research. Details about land structure and plant and animal production were obtained directly from farms, based on a special questionnaire. Some of the data came from farms' identify cards at the community office. These cards are prepared for implementing the Nitrates Directive (91/676/EEC) [8] and action program in nitrogen-vulnerable zones (NVZs). The chosen farms varied in size, production, and specialization. Farms were located in 23 places and 9 communes (Dobrzyca, Kobylin, Koźmin Wielkopolski, Krotoszyn, Ostrów Wielkopolski, Raszków, Rozdrażew, Sulmierzyce, and Zduny).

For the purposes of this research the species of crops cultivated in each of the investigated farms on arable land were counted. The species distinguished on farms included

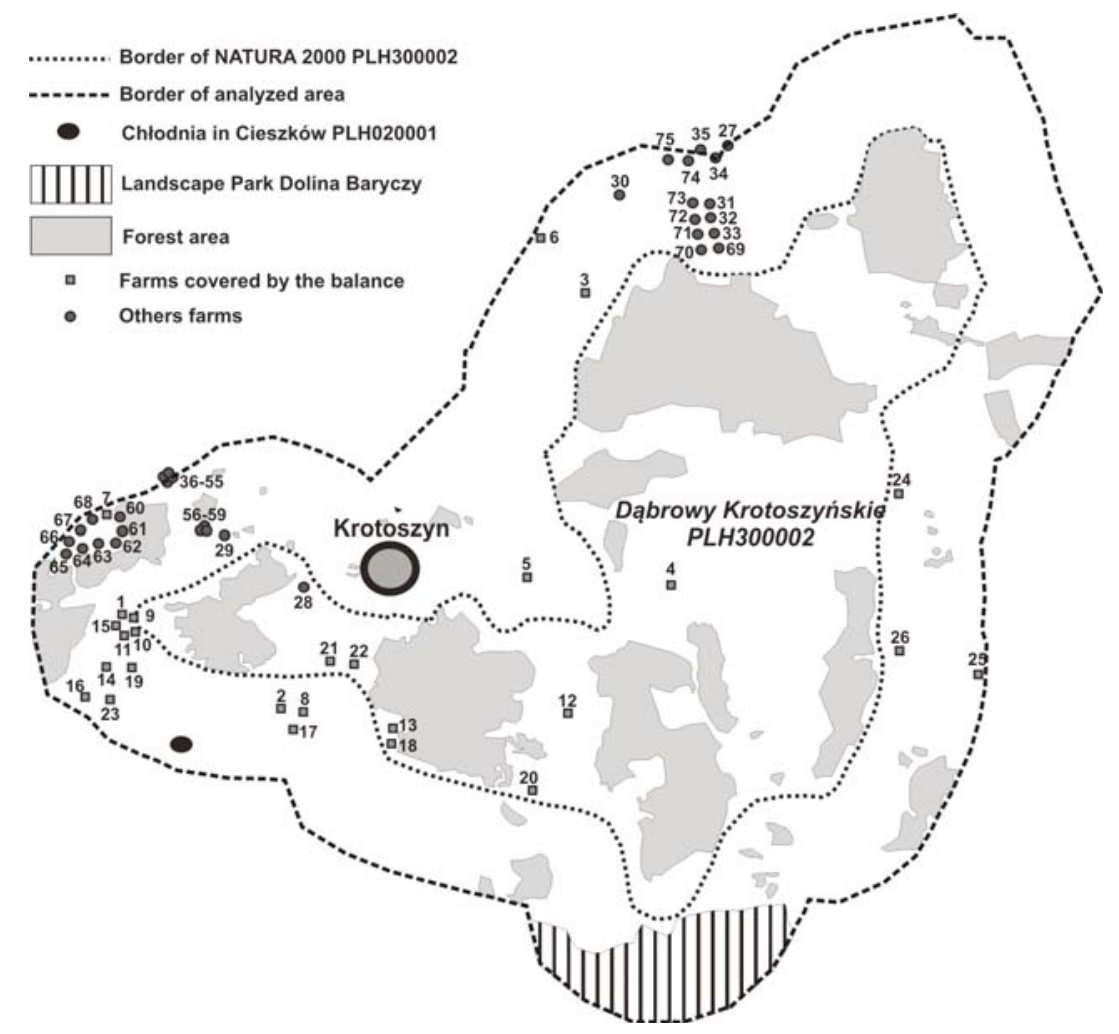

Fig. 2. The analyzed area of NATURA 2000 Dąbrowy Krotoszyńskie with farm locations. 
basic cereals (rye, triticale, wheat, oats, and barley) and plants with colourful perianth which improve the aesthetics of the landscape, break up the monotonous monoculture of cereals, and benefit nectar for bees and other pollinators. Plants with colourful perianth included thick and smallseed legumes (Fabaceae), Brassicaceae, Boraginaceae, Solanaceae, Asteraceae, Apocynaceae, Amaranthaceae, and some herbs. (Among plants with colourful flowers, only those whose cultivation allowed flower production were counted; biennial species that were grown only for a year were not included in this group as they do not produce flowers in the first year of cultivation). The occurrence of different species of livestock was also counted for the selected farms.

Species diversity was assessed using a Shannon-Wiener index $-\mathrm{H}^{\prime}$ [9] on the basis of the plant and livestock species diversity:

$$
H^{\prime}=-\sum_{i=1}^{S} p_{i} \ln p_{i}
$$

...where:

$S$-number of species

$p_{i}$-the ratio of the number of individuals of a given species

to the total number of individuals of all species: $\frac{n_{i}}{N}$

$n_{i}$-number of individuals i-this species

$N$-number of all individuals from all species

The number of animals used in the calculation of the Shannon-Wiener index was based on a previously calculated state annual average inventory $[10,11]$.

For the assessment of species diversity two synthetic indicators were calculated: species diversity and so-called marginal species. Species diversity was calculated by assigning one point to each species of crops and animals. This was used for the purpose of the following formula:

$$
S D=C_{S}+L_{S}
$$

...where:

SD - species diversity

$C_{S}$ - total points for number of crop species

$L_{S}$ - total points for number of livestock species

The indicator of marginal species was based on a scale of valuation. Each species of crop and livestock was assigned one point. Then the indicator was calculated according to the following formula:

$$
M S=\left(C_{S}-B_{S}\right)+\left(L_{S}-L_{P}-L_{C}\right)
$$

...where:

$M S$ - indicator of margin of species

$C_{S}$ - total points for number of crop species

$B_{S}$ - points for number of species of basic cereals

$L_{S}$ - total points for number of livestock species

$L_{P}$ - point for pigs

$L_{C}$ - point for cattle

In addition, the area ratio of crop rotation was calculated by defining the average area per plant species on the

\begin{tabular}{|c|c|c|c|}
\hline Parameter & Unit & Range & Average \\
\hline Farm area & [ha] & $2.8-650.0$ & 37.8 \\
\hline \multirow{2}{*}{ Till lands } & [ha] & $2.3-525.0$ & 32.6 \\
\hline & {$[\%]$} & $50.0-100.0$ & 86.9 \\
\hline \multirow{2}{*}{ Grassland } & [ha] & $0.0-87.0$ & 4.0 \\
\hline & {$[\%]$} & $0.0-45.8$ & 10.3 \\
\hline \multirow{2}{*}{ Woods } & [ha] & $0.0-14.0$ & 0.5 \\
\hline & {$[\%]$} & $0.0-25.0$ & 1.5 \\
\hline \multirow{2}{*}{ Other lands } & [ha] & $0.0-24.0$ & 0.5 \\
\hline & {$[\%]$} & $0.0-6.7$ & 0.6 \\
\hline \multirow{2}{*}{$\begin{array}{l}\text { Livestock } \\
\text { summary }\end{array}$} & [LSU] & $4.4-505.6$ & 41.8 \\
\hline & [LSU $\left.\cdot \mathrm{ha}^{-1}\right]$ & $0.1-7.7$ & 1.5 \\
\hline \multirow{2}{*}{ Cattle } & [LSU] & $0.0-332.2$ & 26.0 \\
\hline & {$\left[\mathrm{LSU} \cdot \mathrm{ha}^{-1}\right]$} & $0.0-4.6$ & 0.9 \\
\hline \multirow{2}{*}{ Pigs } & [LSU] & $0.0-173.4$ & 15.3 \\
\hline & {$\left[\mathrm{LSU} \cdot \mathrm{ha}^{-1}\right]$} & $0.0-3.4$ & 0.5 \\
\hline \multirow{2}{*}{ Other animals } & [LSU] & $0.0-13.1$ & 0.5 \\
\hline & [LSU $\left.\cdot \mathrm{ha}^{-1}\right]$ & $0.0-2.1$ & 0.04 \\
\hline
\end{tabular}
farm, for which the following formula was used:
Table 1 . The chosen parameters of the analyzed farms.

$$
C A=\frac{N_{S}}{S_{A}}
$$

...where:

$C A$ - indicator of crop rotation area

$N_{S}$ - number of crop species

$S_{A}-$ sown area

\section{Results and Discussion}

The NATURA 2000 Dąbrowy Krotoszyńskie area (PLB 300007) has been under the regulation of the Minister of the Environment since 12 January 2011 for the Special Protection of Bird Areas [12], in accordance with Directive 2009/147/EC [13]. The area covers 34,245.3 ha and is one of the biggest and best-known oak forest complexes in Europe. A further $88 \%$ of the area is taken by the Dąbrowy Krotoszyńskie Baszków-Rochy protected landscape area (55,800 ha). The NATURA 2000 Dąbrowy Krotoszyńskie area is covered almost completely by the NATURA 2000 Dąbrowy Krotoszyńskie Special Area of Conservation (PLH300002), which is a very important area for the European Community as a Site of Community Importance (SCI). This zone was approved in 2007, has an area of 34,225.2 ha, and contains 12 habitat types from Appendix I of Council Directive 92/43/EEC [14], three of which are priority. Dąbrowy Krotoszyńskie is located in two NVZ 
areas, which contain the Orla, Czarna Woda, and Kuroch river catchment areas.

The main threats to the analyzed NATURA 2000 zone are changes in water quality and regime, incorrect forest management, and intensive and irrational agri-management. In the $15 \mathrm{~km}$ zone southeast of Dąbrowy Krotoszyńskie there is the Chłodnia Cieszków NATURA 2000 area (PLH020001). This covers an area of 18.7 hectares and is a large, underground brick ice cellar, located in the forest.

\section{Characteristics of Farms}

The average size of the chosen farms was 37.8 ha. Regarding land use, attention needs to be paid to the large proportion of arable ground, which is usually around $86.9 \%$ (Table 1). According to Havranek et al. [15] and Drzewiecki [16] it is very important to diversify land use in order to create exceptionally favorable conditions for recreation in rural areas. A significant share of forests, water, wasteland, trees, shrubs, and grassland allows the mixing of semi-natural ecosystems with typical agricultural ecosystems. Grassland covered about $10 \%$ of the analyzed farms. According to the cross-compliance recommendations, approx. $17 \%$ of farms should be grassland. According to Drzewiecki [16], ecological areas, including grassland, should constitute a minimum of $12+15 \%$ of farms. The diversity of cultivated plants on farmland is also very important. In the analyzed region farmers mostly sow cereal plants on their land, amounting to $96 \%$ of the sown area. Apart from cereals and cereal mixes, also cultivated were industrial plants $(2 \%)$, fodder plants $(1 \%)$ and others, including roots, legumes, and vegetables.

Animal production was characterized by the low diversity in animal species. The average density of livestock was 1.4 LSU (livestock unit). Among the species studied, cattle $(62.1 \%)$ was highest, swine accounted for $36.6 \%$, horses (1.0\%), and hens, goats, turkeys, ducks, sheep, and pigeons totalled around $0.3 \%$. These farms represent a significant threat to the environment - especially water quality [17] due to their manure storage infrastructure and the management of certain macronutrients .

\section{Agro-Biodiversity}

In developing the requirements of 'greening' under Pillar I of the Common Agricultural Policy (CAP), great attention was paid to the variety of agricultural production in terms of the structure of the land and the crops cultivated. The introduction of these requirements was intended to improve the environmental performance of the CAP by supporting environmental measures applicable throughout the EU in order to introduce a mandatory 'ecological' component in future direct payments. The obligations arising from the planned requirements of 'greening' are primarily to maintain the existing areas of grassland on farms, plan a minimum of three crops in crop rotation (or a minimum of two crops if the holding is less than 10 hectares), but a sin-
Table 2. The results of agro-biodiversity in the analyzed farms.

\begin{tabular}{|c|c|c|c|}
\hline Specification & Value & $\mathrm{H}^{\prime}$ & $\begin{array}{c}\text { Number of } \\
\text { species }\end{array}$ \\
\hline \multirow{2}{*}{$\begin{array}{c}\text { Biodiversity of } \\
\text { crops H' }\end{array}$} & range & $0.00-2.21$ & $1-13$ \\
\cline { 2 - 4 } & average & 1.52 & 7 \\
\hline $\begin{array}{c}\text { Biodiversity of } \\
\text { livestock H' }\end{array}$ & range & $0.00-1.35$ & $1-5$ \\
\cline { 2 - 4 } & average & 0.59 & 2 \\
\hline
\end{tabular}

Table 3. The share of farms with determined number of species.

\begin{tabular}{|c|c|c|c|c|c|}
\hline \multirow{2}{*}{ Specification } & \multirow{2}{*}{ Unit } & \multicolumn{4}{|c|}{$\begin{array}{c}\text { Range specifies the number of } \\
\text { species }\end{array}$} \\
\hline & & $<3$ & $3-5$ & $6-8$ & $>8$ \\
\hline $\begin{array}{l}\text { Farms with total } \\
\text { number of species }\end{array}$ & \multirow{3}{*}{$\begin{array}{c}\text { Share } \\
{[\%]}\end{array}$} & 5 & 23 & 51 & 21 \\
\hline $\begin{array}{l}\text { Farms with basic } \\
\text { cereals }\end{array}$ & & 8 & 92 & 0 & 0 \\
\hline $\begin{array}{l}\text { Farms with plants } \\
\text { with colourful flowers }\end{array}$ & & 64 & 5 & 0 & 0 \\
\hline
\end{tabular}

gle species should not exceed $75 \%$ of the sowing structure and should not be less than 5\%. The two main crops cannot exceed $95 \%$ of arable land. In addition, $5 \%$ of agricultural land should be allocated to a so-called area of ecological compensation (ecological focus area) for the majority of farms larger than 15 hectares, e.g. balk, hedges, trees, fallow land, landscape, habitats, buffer zones, and forested areas. This percentage may rise to $7 \%$ after the presentation by the commission in 2017 of a report and legislative proposal [18]. In the analyzed farms forested areas accounted for only $1.5 \%$ of land use. Other land accounted for a marginal proportion (Table 1). 'Greening' is intended to provide environmental benefits by keeping carbon in the soil, species protection on permanent grassland, water conservation, ecological compensation, and improving the regenerative capacity of ecosystems through crop diversification. The requirements of 'greening' will be mandatory for organic farms, including those located partially or completely in NATURA 2000 areas.

Analysis of species diversity of crops in the investigated farms showed that a total of only 13 species of plants were cultivated in different combinations on different farms. The number of species on individual farms amounted to an average of seven (Table 2). Ninety-five percent of the farms studied meet the requirements of 'greening' as they have a minimum of three species of arable crop. As many as $51 \%$ cultivated $6-8$ species (Table 3 ). Of the surveyed farms and five had an area of less than 10 hectares. In such farms the number of species in crop rotation should not be less than two. However, one of the small farms did not meet this standard. Basic cereals were found to be grown by many farms, with four species cultivated by the 
Table 4. The indicators of diversity in analyzed farms.

\begin{tabular}{|c|c|c|c|c|c|c|c|}
\hline \multirow[b]{2}{*}{ Farm number } & \multicolumn{3}{|c|}{ Indicator } & \multirow[b]{2}{*}{ Farm number } & \multicolumn{3}{|c|}{ Indicator } \\
\hline & $\begin{array}{l}\text { Crop rotation } \\
\text { area } \mathrm{CA}\end{array}$ & $\begin{array}{c}\text { Species } \\
\text { diversity SD }\end{array}$ & $\begin{array}{c}\text { Marginal } \\
\text { species MS }\end{array}$ & & $\begin{array}{l}\text { Crop rotation } \\
\text { area } \mathrm{CA}\end{array}$ & $\begin{array}{c}\text { Species } \\
\text { diversity SD }\end{array}$ & $\begin{array}{c}\text { Marginal } \\
\text { species MS }\end{array}$ \\
\hline 1 & 24.7 & 7 & 1 & 39 & 1.3 & 10 & 5 \\
\hline 2 & 9.2 & 7 & 2 & 40 & 1.7 & 10 & 6 \\
\hline 3 & 11.3 & 7 & 3 & 41 & 6.4 & 9 & 4 \\
\hline 4 & 2.3 & 7 & 2 & 42 & 4.4 & 9 & 2 \\
\hline 5 & 24.8 & 4 & 3 & 43 & 2.6 & 12 & 6 \\
\hline 6 & 3.3 & 7 & 9 & 44 & 1.6 & 10 & 7 \\
\hline 7 & 7.3 & 5 & 0 & 45 & 1.8 & 10 & 4 \\
\hline 8 & 3.7 & 10 & 3 & 46 & 0.9 & 13 & 8 \\
\hline 9 & 1.8 & 5 & 2 & 47 & 1.8 & 13 & 8 \\
\hline 10 & 2.3 & 8 & 4 & 48 & 0.7 & 14 & 9 \\
\hline 11 & 6.0 & 5 & 1 & 49 & 2.7 & 15 & 10 \\
\hline 12 & 1.0 & 8 & 3 & 50 & 1.1 & 12 & 7 \\
\hline 13 & 0.4 & 6 & 2 & 51 & 3.2 & 10 & 7 \\
\hline 14 & 8.8 & 6 & 0 & 52 & 1.4 & 12 & 7 \\
\hline 15 & 5.2 & 6 & 1 & 53 & 1.5 & 10 & 3 \\
\hline 16 & 3.0 & 4 & 0 & 54 & 2.2 & 9 & 6 \\
\hline 17 & 5.0 & 3 & 0 & 55 & 4.3 & 10 & 3 \\
\hline 18 & 6.0 & 6 & 0 & 56 & 3.8 & 11 & 5 \\
\hline 19 & 2.7 & 7 & 5 & 57 & 1.6 & 11 & 5 \\
\hline 20 & 3.8 & 9 & 5 & 58 & 3.4 & 5 & 2 \\
\hline 21 & 3.6 & 11 & 6 & 59 & 1.2 & 11 & 6 \\
\hline 22 & 4.2 & 10 & 3 & 60 & 1.7 & 12 & 6 \\
\hline 23 & 4.3 & 4 & 0 & 61 & 1.4 & 11 & 7 \\
\hline 24 & 3.6 & 6 & 2 & 62 & 1.3 & 14 & 9 \\
\hline 25 & 11.1 & 4 & 0 & 63 & 0.9 & 12 & 7 \\
\hline 26 & 7.3 & 6 & 4 & 64 & 1.7 & 13 & 7 \\
\hline 27 & 3.9 & 8 & 6 & 65 & 1.8 & 14 & 8 \\
\hline 28 & 1.2 & 8 & 6 & 66 & 1.3 & 12 & 6 \\
\hline 29 & 2.3 & 13 & 8 & 67 & 5.8 & 7 & 2 \\
\hline 30 & 2.6 & 11 & 6 & 68 & 5.9 & 5 & 4 \\
\hline 31 & 2.7 & 12 & 7 & 69 & 2.1 & 11 & 7 \\
\hline 32 & 2.2 & 13 & 8 & 70 & 2.7 & 12 & 8 \\
\hline 33 & 14.6 & 9 & 4 & 71 & 2.2 & 13 & 8 \\
\hline 34 & 3.3 & 10 & 6 & 72 & 14.6 & 9 & 4 \\
\hline 35 & 4.0 & 9 & 4 & 73 & 5.4 & 12 & 7 \\
\hline 36 & 40.4 & 15 & 12 & 74 & 3.3 & 10 & 6 \\
\hline 37 & 0.7 & 6 & 3 & 75 & 4.0 & 9 & 4 \\
\hline 38 & 4.7 & 9 & 3 & Average & 4.7 & 9 & 5 \\
\hline
\end{tabular}


Table 5. The range of results for biodiversity in the analyzed farms.

\begin{tabular}{|l|c|c|c|c|c|}
\hline \multirow{2}{*}{ Type of biodiversity H' } & \multicolumn{5}{|c|}{ Range of H' } \\
\cline { 2 - 6 } & $0.00-0.50$ & $0.51-1.00$ & $1.01-1.50$ & $1.51-2.00$ & $>2.01$ \\
\hline Crops in the different ranges [\%] & 2.7 & 6.7 & 33.3 & 48.0 & 9.3 \\
\hline Livestock in the different ranges [\%] & 40.0 & 33.3 & 26.7 & - & - \\
\hline
\end{tabular}

Table 6 . The share of farms with a determined number of livestock species.

\begin{tabular}{|c|c|c|c|c|c|}
\hline \multirow{2}{*}{ Specification } & \multirow{2}{*}{ Unit } & \multicolumn{4}{|c|}{ Range specifies the number of species } \\
\cline { 3 - 6 } & & $<3$ & $3-5$ & $6-8$ & $>8$ \\
\hline Farms with a total number of species & Share [\%] & 51 & 49 & 0 & 0 \\
\hline
\end{tabular}

average farm. A special role in the development of agroecosystems and the appearance of the landscape is played by plants with colourful flowers, which also are of use to many beneficial insects such as hymenoptera, lepidoptera, dipterans, and coleopteran [19-21]. Cereals may look aesthetically pleasing in ribbon systems, which occur almost exclusively in the mountains [22]. In the studied farms this was a small group represented mainly by rape, mustard, agrimonia, potatoes, alfalfa, clover, peas, and pumpkin, with one species per farm. The ratio of the total number of plant species for basic cereals and plants with colourful flowers was 1:0.6:0.2. The surface area taken by crops other than cereal was small, amounting to only $4 \%$. As shown by the results obtained from the studied farms, a very simple sowing structure was used. According to Kuś [23], an increase in specialization and simplification of crop rotation, consisting of reducing the number of plants, leads to increased usage of means of production, especially fertilizers, in terms of the inefficient use of nutrients. Intensification of agricultural production can lead to significant degradation of the environment and increase the risk of agroecosystem instability, thus reducing the production potential of agrocenosis [24, 25].

Some authors argue that in order to develop the recreational functions of villages, attention should be paid to all features and components of the landscape [16, 26, 27]. One of the characteristics described by these authors is the size of crop rotation fields. According to Drzewiecki [16], they should not be larger than 10 ha and should contain different crop species every 300-400 m. Drzewiecki's [16] analysis showed that for one species there is an average of 4.7 hectares of arable land. These areas were larger than 10 ha in only 7 farms. The calculated species diversity index, taking into account the number of crops and livestock, was $\mathrm{SD}=9$. On the other hand, the margin species indicator specifying the number of marginal plants and animals on farms, with the exception of the most popular crops and livestock, averaged $\mathrm{MS}=5$ (Table 4 ). The margin therefore constituted $56 \%$ of all species of plants and animals on the farms.

The biodiversity $\mathrm{H}^{\prime}$ crops amounted to an average of 1.52 (Table 2). According to some authors, the most com- mon range for biodiversity of natural ecosystems is $\mathrm{H}^{\prime}$ from 1.5 to 3.5 . The index rarely exceeds 4.0 [28]. The distribution results of the biodiversity of crops and livestock are shown in Table 5. In terms of plant biodiversity, a lower rate was observed in the small farms and farms with an area of over 50 hectares. Livestock species diversity decreased as farm size increased (Fig. 3). This could be caused by narrow specialization. Large farms are most often like corporations, involving no domestic consumption. Small farms are family businesses, maintaining additional animals for their own needs.

Regarding animals in the group of analyzed farms, a total of nine species were reported, but the dominant species were cattle and pigs - found in $65 \%$ of farms. These are species which give fast and reliable capital turnover. Up to 5 species were found on any one farm, but on average there were just two species per farm (Table 2). Less than 3 species of farm animals are kept by $51 \%$ of farmers (Table 6 ). The proportion of animals other than cattle and pigs was only $1.3 \%$. These animals are commonly kept for domestic use. Many of these marginal animals perform very important ecological functions. Sheep, mainly indigenous breeds, play a special role in protecting the environment and landscape. These animals graze in marginal or less-favoured areas (mountains, floodplains) and help to maintain agri-

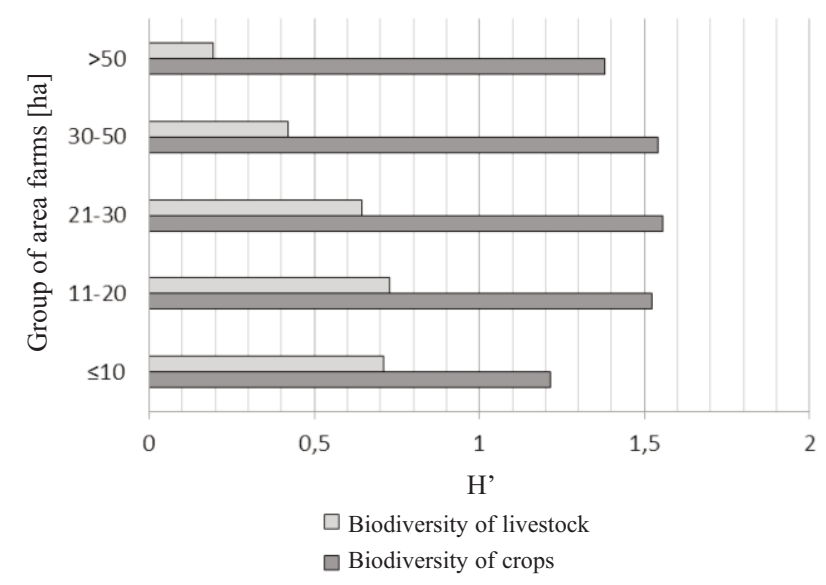

Fig. 3. The biodiversity in area groups of the analyzed farms. 
culture and production potential while preserving biodiversity. Sheep are relatively small and active, move easily in areas with highly varied terrain, cut the grass short, and massage it with their hooves. Animal manure also plays an important role in maintaining biodiversity. The excreta of these animals are a rich source of nutrients for plants, as well as a dietary component of many species of invertebrates, birds, and mammals [29].

The biodiversity of crops and livestock affects the biodiversity of species inhabiting wild agrocoenosis. The types of crops grown affect not only the formation of soil habitat, but also the associated environment and ecosystems [30]. Some authors say that a mosaic-like cultivation structure increases the number of insect species by $20 \%$, and their biomass by $50 \%[31,32]$. The Dąbrowy Krotoszyńskie area contains not only forests, but also peatmosses, peat bogs, meadows, pastures, and arable land. The diversity of these habitats depends to some extent on the structure of the crops sown in the surrounding areas as cereal cultivation can cause environmental indicators in the region to deteriorate. As shown by some authors, monoculture cultivation of cereals entails the consumption of large quantities of pesticides and fertilizers, which often spread into the environment. Nitrogen from fertilizers and manures adversely affects forest ecosystems, making them weaker and more susceptible to degradation. The excess of nitrogen in wet meadows and wetlands reduces biodiversity and affects species composition. Moreover, fewer insects inhabiting farmland, mostly as a result of the increased use of plant protection products, may adversely affect the avifauna of the region. This may in turn result in an impaired trophic chain and biocenotic homeostasis. The low diversity of cultivated species found in the analyzed farms can therefore potentially interfere with the functioning of the Dąbrowy Krotoszyńskie NATURA 2000 area, due to the deterioration of the landscape, tourism development, the deterioration of environmental indicators, and the functioning of natural ecosystems in the region.

\section{Conclusions}

1. The number of species of plants grown in the analyzed farms in relation to the requirements of 'greening' was correct. However, cereals are grown on $96 \%$ of the area. Other species, including those with colourful flowers, accounted for only $4 \%$ of the crop.

2. Diversity of animals in the surveyed farms was low. Farmers mostly kept cattle and sheep. A few other species were kept for domestic use.

3. Diversity of plants was highest in the mid-sized farms. Animal biodiversity decreased with increasing farm size, probably due to greater specialization of production in larger farms.

4. Diversification of land use in analyzed farms was low, mainly dominated by arable land. Other categories of land use, important from the point of view of increasing biodiversity, were few and insufficient in terms of the requirements of 'greening.'

\section{References}

1. FAO. Status and trends of animal genetic resources - 2008 . Intergovernmental Technical Working Group on Animal Genetic Resources for Food and Agriculture, 12 Fifth Session, Rome, 28 - 30 January 2009 CGRFA/WG - AnGR -5/09/Inf. 7. Available at:

ftp://ftp.fao.org/docrep/fao/meeting/016/ak220e.pdf). 2009.

2. The State of the World's Animal Genetic Resources for Food and Agriculture. The state of the world's. Animal genetic Resources for food and agriculture - in brief. Commission on Genetic Resources for Food and Agriculture. F AND Agriculture Organization of the United Nations. Rome. Available at: ftp://ftp.fao.org/docrep/fao/010/a1260e/a1260e00.pdf. 2007.

3. BALEZENTIENE L. Alpha-Diversity of Differently Managed Agro-Ecosystems Assessed at a Habitat Scale. Pol. J. Environ. Stud. 20, (6), 1387, 2011.

4. Convention on Biological Biodiversity dated. June 5, 1992. Union. Journal of Law 2002 No. 184, item 1532. Available at: http://www.nid.pl/upload/iblock/ed8/ed8f84604e78aecc 827b0a0d162a7870.pdf). 1992.

5. National strategy for the conservation and sustainable use of biodiversity, including the Programme of Action for 20072013, approved by Resolution No. 270/2007 Council of Ministry of 26 October 2007. Available at:

http://biodiv.gdos.gov.pl/wdrazanie-konwencji/nationalstrategy-conservation-and-sustainable-use-biodivesity-polish/ krajowa-strategia-ochrony-i-zrownowazonego-uzytkowania-roznorodnosci). 2007 [In Polish].

6. O'ROURKE E., KRAMM N., CHISHOLM N. The influence of farming styles on the management of the Iveraghuplands, southwest Ireland. Land Use Policy, 29, 805, 2012.

7. SUTKOWSKA B., ROZBICKI J., GOZDOWSKI D. Farming Systems in High Nature Value (HNV) Farmland: a Case Study of Wigry National Park, Poland. Pol. J. Environ. Stud. 22, (2), 521, 2013.

8. The Nitrates Directive. Council Directive 91/676/EEC of 12 December 1991 concerning the protection of waters against pollution caused by nitrates from agricultural sources. Union. Journal of Law No WE L 375 from 31. 12. 1991.

9. SHANNON C.E. A mathematical theory of communication. Bell System Technical J. 27, 379-423, 623-656, 1948.

10. Ministry of the Environment Ordinance dated 23 Dec. 2002 on detailed requirements for limiting nitrogen run-off from agricultural sources oriented programs. Union. Journal of Law No. 4, item. 44, 2002 [In Polish].

11. Ministry of the Environment Ordinance dated 18 may 2005 on detailed conditions and procedures of financial help providing for conformance of farms to European Union standards involved of Rural Development Programme. Union. Journal of Law No. 93, item 778, 779, and 780. 2005 [In Polish].

12. Regulation of the Minister of Environment of 12 January 2011 concerning special protection of birds areas. Union. Journal of Law 2011 No. 25 item 133. Available at: http://isip.sejm.gov.pl/DetailsServlet?id=WDU20110250133. 2011.

13. Directive 2009/147/EC of the European Parliament and of the Council on the conservation of wild birds. EUR-Lex32009L0147-EN. Available at http://eur-lex.europa.eu/legalcontent/EN/TXT/?uri=CELEX:32009L0147. 2009.

14. Council Directive 92/43/EEC of 21 May 1992 on the conservation of natural habitats and of wild fauna and flora. Union. Journal of Law No L 206, 22/07/1992 P. 0007 0050. 1992. 
15. HAVRANEK F., PAVLIS J., HUCKO B., CZUDEK R. Alternative Utilisation of Agricultural Land. Scientific Monograph. ISBN 978-80-902617-6-1. Edited by Rembrant. 144, 2007.

16. DRZEWIECKI M. Rural recreation space. Instyt. Turysty. Warszawa. 19, 1992 [In Polish].

17. KUPIEC J. M. Estimation of selected agri-environmental indicators in farms located in direct influence zone on Natura 2000 area Dąbrowy Krotoszyńskie (PLH300002). Ann. Warsaw Univ. of Life Sci. - SGGW, Land Reclam. 46, (1), 17, 2014.

18. The European Commission. Reform of the Common Agricultural Policy (CAP) - an explanation of the most important elements. Bruksela. Available at:

www.europa.eu/rapid/press-release MEMO-13-937_pl.pdf. 2013.

19. DECOURTYE A., MADER E., DESNEUX N. Landscape enhancement of floral resources for honey bees in agroecosystems. INRA/DIB-AGIB/EDP Sciences. Apidologie 41, 264, 2010

20. KOSTUCH R. Landscape and agriculture in the mountains. Wyd. FCEEW Krosno, pp. 40, 1997 [In Polish].

21. RICKETTS T.H., REGETZ J., STEFFAN-DEWENTER I., CUNNINGHAM S.A., KREMEN C., BOGDANSKI A., GEMMILL-HERREN B., GREENLEAF S.S., KLEIN A.M., MAYFIELD M.M., MORANDIN L.A., OCHIENG A., VIANA B.F. Landscape effects on crop pollination services: are there general patterns? Ecol. Lett. 11, 499, 2008.

22. LIPSKI C., KOSTUCH R. Management the landscape of eroded areas Acta Agrophysica, 5, (2), 245, 2005 [In Polish].

23. KUŚ J. Farming systems. Organic farming. Training Materials 45/95. IUNG Puławy, pp. 62, 1996 [In Polish].

24. TRYBAŁA M. The production and storage of agricultural crops. Wyd. AR Wrocław, pp. 530, 1999 [In Polish].
25. KUPIEC J. The balance of organic matter in soil of selected farms located in the sensitive water catchment area. Nauka Przyr. Technol. 4, 4, 49, 2010 [In Polish].

26. BELAIR C., ICHIKAWA K., WONG B.Y. L., MULONGOV K.J. (Edit.). Sustainable use of biological diversity in socio-ecological production landscapes. Background to the 'Satoyama Initiative for the benefit of biodiversity and human well-being. Secretariat of the Convention on Biological Diversity, Montreal. Technical Series No. 52, 184. 2010.

27. KUPIDURA A., ŁUCZEWSKI M., KUPIDURA P. (Edit.). The value of the landscape. The development of the rural areas. Wyd. Nauk. PWN. Warszawa. pp. 106, 2011 [In Polish].

28. MAGURRAN, A.E. Measuring Biological Diversity, Blackwell Publishing. Oxford, UK. pp. 256, 2004.

29. LECHOWSKA J., AUGUSTYŃSKA-PREJSNAR A., ORMIAN M. The use of sheep in a mountain landscape conservation. Zesz. Nauk. Południowo-Wschodniego Oddziału Polskiego Towarzystwa Inżynierii Ekologicznej i Polskiego Towarzystwa Gleboznawczego. Rzeszów. 11, 165, 2009 [In Polish].

30. JASKULSKI D., JASKULSKA I. Share of Agricultural Land in Spatial Variation in Plant Cover of Kujawy and Pomorze Province. Pol. J. Environ. Stud. 20, (3), 571, 2011.

31. RYSZKOWSKI L., KARG J., KUJAWA K., GOŁDYN H., ARCZYŃSKA-CHUDY E. Influence of landscape mosaic structure on diversity of wild plant and animal communities in agricultural landscapes of Poland. In: Landscape ecology in agroecosystems management. (Ed.) L. Ryszkowski. CRS Press, Boca Raton, New York, Washington DC. 185-217, 2002.

32. Tools for Conservation and Use of Pollination Services. Initial survey of good pollination practices. Pollination Services for Sustainable Agriculture. FAO. Rome. www.fao.org/ag/AGP/default.htm. 133, 2008. 